\title{
Potentiality of Achatina fulica Bowdich, 1822 (Mollusca: Gastropoda) as intermediate host of the Angiostrongylus costaricensis Morera \& Céspedes 1971
}

\author{
Adhatina fulica Bowdich, 1822 (Mollusca: Gastropoda) como hospedeiro intermediário \\ potencial do Angostronglus costaricensis Morera \& Céspedes 1971
}

\author{
Omar dos Santos Carvalho', Horácio MS Teles², Ester Maria Mota ${ }^{3}$, Cristiane Lafetá \\ Gomes Furtado de Mendonça ${ }^{1,4}$ e Henrique Leonel Lenzi ${ }^{3}$
}

\begin{abstract}
Resumo Exemplares de Achatina fulica foram experimentalmente infectados com larvas de Angiostrongylus costaricensis, agente etiológico da angiostrongiliase abdominal, mostrando-se susceptíveis ao parasita. Achatina fulica pode representar um risco para a urbanização da angiostrongilíase abdominal devido a sua alta prolificidade contínua dispersão e notável adaptação a ambientes urbanos.
\end{abstract}

Palavras-chaves: Achatina fulica. Angiostrongylus costaricensis. Infecção experimental. Angiostrongilíase abdominal.

Abstract Samples of Achatina fulica were experimentally infected with Angiostrongylus costaricensis larvae, etiological agent of abdominal angiostrongyliasis, showing that $A$. fulica is susceptible to the parasite. Achatina fulica may be a risk to urbanization of abdominal angiostrongyliasis presumably due to its high proliferation, continuous dispersion and remarkable adaptation in several Brazilian towns.

Key-words: Achatina fulica. Angiostrongylus costaricensis. Experimental infection. Abdominal angiostrongyliasis.

Achatina fulica is a large generalist herbivorous and very prolific snail, samples of which can reach $10 \mathrm{~cm}$ in length and weigh up to $100 \mathrm{~g}$ in Brazil. This snail plays an important role in the life cycle of Angiostrongylus cantonensis, the etiological agents of eosinophilic meningoencephalitis, in Africa and in the pan-Pacific region ${ }^{5}$. Most of the reports about environmental invasions by $A$. fulica are related to urban or periurban areas as a consequence of its domestic breeding for commercial marketing as escargots. Professionals working in this field indicate that this mollusk has been widespread over many localities and municipalities of the Northeastern, Centralwestern, Southwest and South regions of Brazil.

The first report on the environmental invasion of A. fulica, giant or African snail, was in the municipality of Itariri, in the State of São Paulo, Brazil, in which its dispersion and possible risk of transmission of A. costaricensis aetiologic agent of abdominal angiostrongyliasis in the Americas ${ }^{15}$, were remarked.

In the State of São Paulo, the presence of $A$. fulica was reported in Peruíbe, Itanhaém, Monguagá, Praia Grande, São Vicente, Santos, Guarujá, São Sebatião, Ilha Bela, Caraguatatuba, Ubatuba, along the coastline of Jacupiranga, Registro, Iporanga, Ribeira do Iguapé region, Aparecida, Guaratinguetá, Cruzeiros, Taubaté, Cachoeira Paulista, Paraíba do Sul Valley and the city of São Paulo. Also in the countryside of the State of São Paulo: Tietê, Sorocaba, Bragança Paulista, Piracaia, Nazaré Paulista, Jarinu, Mairipirã, Jundiaí, Atibaia, Votuporanga, Paulicéia, Panorama, Presidente Prudente, Bom Jesus dos Perdões, Campinas, Rio

1. Centro de Pesquisas René Rachou da Fundação Oswaldo Cruz, Belo Horizonte, MG, Brasil. 2. Superintendência de Controle de Endemias, São Paulo, SP, Brasil. 3. Departamento de Patologia do Instituto Oswaldo Cruz da Fundação Oswaldo Cruz, Rio de Janeiro, RJ, Brasil. 4. Pontifícia Universidade Católica de Minas Gerais, Belo Horizonte, MG, Brasil.

Endereço para correspondência: Dr Omar dos Santos Carvalho. Av. Augusto de Lima 1715, 30190-002 Belo Horizonte, MG, Brasil.

Fax: $55313295-3115$

e-mail: omar@cpqrr.fiocruz.br

Recebido para publicação em 3/9/2003

Aceito em 16/10/2003 
Claro, Pedreiras, Santo André. The snail was also detected in the states of Bahia, Espírito Santo, Goiás, Minas Gerais, Pará, Paraíba, Pernambuco, Piauí, Rio de Janeiro, Rondônia, and Santa Catarina ${ }^{14}{ }^{17} 18$, as well as, in the locality of Chacao, Miranda, in Venezuela ${ }^{10}$

There is a wide variety of mollusks involved in the transmission of $A$. costaricensis, detected in several states of the Southeast and South regions of Brazil. Its transmission is mainly associated with slugs from the family Veronicellidae. The most important species are Sarasinula plebeius in Central America, Phyllocaulis variegatus ${ }^{3}$ and $S$. linguaeformis ${ }^{6}$, in Brazil. Other snails such as Limax maximus, L. flavus, Bradybaena similaris ${ }^{4}$, Belocaulus angustipes ${ }^{3}$, P. soleiformis, Helix aspersa ${ }^{16}$ and Deroceras laeve ${ }^{11}$ were also reported with natural infections. On the other hand, the literature records a great variety of mollusk species experimentally infected with Angiostrongylus costaricensis, thus showing to be highly nonspecific to the intermediate host. In fact, other terrestrial and aquatic mollusks, experimentally infected, such as Veronicella occidentalis ${ }^{9}, S$. marginata $^{7}$, P. boraceiensis ${ }^{1}$, mollusks from the genus Megalobulimus ${ }^{3}$ and the planorbids Biomphalaria tenagophila and B. glabrata ${ }^{8}$ were also susceptible to A. costaricensis, allowing the parasite to develop and eliminate $L_{3}$.

The aim of this study was to test the experimental susceptibility of $A$. fulica to $A$. costaricensis infection. To do so 37 mollusks from the municipality of São Vicente (23s57/46w23) were divided into eight groups (Table 1) and after two months of quarantine, individually exposed to circular lettuce pieces covered with healthy mouse feces and $100 \mathrm{ml}$ of a concentrate containing $L_{1}$. The snails were sacrificed (Table 1) at different times of infection, and the shells were broken in order to have their soft parts exposed and their viscera discarded. The fibromuscular layer of the body was digested ${ }^{19}$ and transferred to a Baerman's funnel. The sediment was gathered into a watch glass and larvae were counted under a stereomicroscope. Viable $\mathrm{L}_{3}$ were divided into groups of 30 specimens and orally inoculated into three Sigmodon hispidus for later identification of adult worms.

\begin{tabular}{|c|c|c|c|c|c|}
\hline Group & $\begin{array}{c}\text { Number of } L_{1} \\
\text { (exposure) }\end{array}$ & $\begin{array}{c}\text { Number of } \\
\text { snails }\end{array}$ & $\begin{array}{c}\text { Days } \\
\text { after exposure }\end{array}$ & $\begin{array}{c}\text { Positive } \\
\text { snails }\end{array}$ & $\begin{array}{l}\text { Number of } \mathrm{L}_{3} \\
\text { after digestion }\end{array}$ \\
\hline I & 1.000 & 8 & 34 & 0 & 0 \\
\hline \multirow[t]{2}{*}{ II } & 3.296 & 5 & 35 & 0 & 0 \\
\hline & & 3 & 45 & 0 & 0 \\
\hline \multirow[t]{2}{*}{ III } & 3.296 & 5 & 50 & 2 & 28 \\
\hline & & & & & 300 \\
\hline IV & 4.400 & 1 & 42 & 0 & 0 \\
\hline \multirow[t]{2}{*}{ V } & 4.580 & 4 & 52 & 2 & 3 \\
\hline & & & & & 3 \\
\hline \multirow[t]{4}{*}{ VI } & 4.860 & 5 & 54 & 4 & 3 \\
\hline & & & & & 200 \\
\hline & & & & & 300 \\
\hline & & & & & 1.000 \\
\hline \multirow[t]{2}{*}{ VII } & 5.180 & 1 & 21 & 1 & 4 \\
\hline & & 1 & 60 & 1 & 400 \\
\hline \multirow[t]{2}{*}{ VIII } & 13.662 & 4 & 39 & 2 & 4 \\
\hline & & & & & 5 \\
\hline
\end{tabular}

Two groups were used as controls: Three infected $S$. marginata snails for each $A$. fulica group (positive control), and three non-infected $A$. fulica snails for mortality control.

Out of 37 snails examined, $12(32 \%)$ eliminated A. costaricensis $\mathrm{L}_{3} ; 7$ showed less than 30 ; and 5 more than $200 \mathrm{~L}_{3}$ (Table 1). All S. marginata controls became infected and all the three non-infected $A$. fulica remained alive up to the end of the experiments. The three $S$. hispidus infected with $\mathrm{L}_{3}$ (from infected $A$. fulica) eliminated $A$. costaricensis $L_{1}$ in the feces 28 days after infection.

Five A. fulica snails were individually infected with 4860 larvae, then sacrificed at 54 days after infection, and fixed in Carson's Formalin-Millonig ${ }^{2}$. Serial cross-sections were stained with hematoxylin and eosin, and observed under brightfield microscopy. Only two A. fulica snails presented well organized granulomas (encapsulation process) in the fibromuscular layer, without evidence of larvae inside of them, similar to those noticed in S. marginata ${ }^{12}$. 
The experiments with $A$. fulica showed that this snail is susceptible to $A$. costaricensis infection, requiring, however, high levels of larval exposure. Although only $32 \%$ of the samples were found to be positive, the parasite burden in $42 \%$ of the snails ranged from 200 to $1000 \mathrm{~L}_{3}$.

Due to the extensive and continued dissemination of these snails all over the Brazilian territory, $A$. fulica could be an additional risk of new abdominal angiostrongylosis clinical cases. After checking its susceptibility, this possibility is high in urban environments, where the mollusk has shown a great capacity of adaptation and survival. The non-specificity of the parasite for intermediate hosts, the great reproductive capacity and rapid dispersion of $A$. fulica, as well as the possibility that the prevalence of abdominal angiostrongylosis could be underestimated (Fauza et al 1990) are determinant factors for a possible $A$. costaricensis urbanization.

This is a preliminary study, and as such another will be carried out with further and more properly designed experiments.

The scope of this work was not to describe a new host, but to afford considerable evidence of the risk to public health related to the fact that $A$. fulica may play an important role as a transmitter of angiostrongylosis. Additionally, this paper attempted to answer various questions of the population in general, ecologists and health professionals.

\section{REFERENCES}

1. Bonetti VCBDO, Graeff-Teixeira C. Angiostrongylus costaricensis and the intermediate hosts: observations on elimination of $L_{3}$ in the mucus and inoculation of $L_{1}$ through the tegument of molluscs. Revista da Sociedade Brasileira de Medicina Tropical 31: 289-294, 1998.

2. Carson FL, Martin JH, Lynn JA. Formalin fixation for electron microscopy: a re-evaluation. American Journal of Clinical Pathology 59: 365-375, 1973.

3. Graeff-Teixeira C, Thiengo SC, Thomé JW, Medeiros AB, CamiloCoura L, Agostini AA. On the diversity of mollusc intermediate hosts of Angiostrongylus costaricensis Morera \& Cespedes, 1971 in Southern Brazil. Memórias do Instituto Oswaldo Cruz 88: 487-489, 1993.

4. Graeff-Teixeira C, Thomé JW, Pinto SCC, Camillo-Coura L, Lenzi HL. Phyllocaulis variegatus an intermediate host of Angiostrongylus costaricensis in South Brazil. Memórias do Instituto Oswaldo Cruz 84: 65-68, 1989.

5. Kliks MM, Palumbo NE. Eosinophilic meningitis beyond the Pacific basin: the global dispersal of a peridomestic zoonosis caused by Angiostrongylus cantonensis, the nematode lungworm of rats. Social Science Medicine 34: 199-212, 1992.

6. Laitano AC, Genro JP, Fontoura R, Branco SSL, Maurer RL, Graeft-Teixeira C, Milanez JM, Chiaradia LA, Thomé JW. Report on the occurrence of Angiostrongylus costaricensis in southern Brazil, in a new intermediate host from the genus Sarasinula (Veronicellidae, Gastropoda). Revista da Sociedade Brasileira de Medicina Tropical 34: 95-97, 2001.

7. Lima LC, Massara CL, Souza CP, Jannoti-Passos LK, Lenzi HL. Sarasinula marginata (Semper, 1885) (Mollusca, Soleolifera) de Belo Horizonte (MG, Brasil) como hospedeira intermediária potencial do Angiostrongylus costaricensis Morera \& Cespedes, 1971. Revista do Instituto de Medicina Tropical de São Paulo 34: 117-120, 1992a.

8. Lima LC, Massara CL, Souza CP, Vidigal TD, Lenzi HL, Carvalho OS. Suscetibilidade de planorbídeos da região metropolitana de Belo Horizonte, MG (Brasil) ao Angiostrongylus costaricensis (Nematoda, Angiostrongylidae). Revista do Instituto de Medicina Tropical de São Paulo 34: 399-402, 1992b.

9. Malek EA. Presence of Angiostrongylus costaricensis Morera and Cespedes, 1971 in Colombia. American Journal of Tropical Medicine Hygiene 30: 81-83, 1981.
10. Martínez ER, Martínez ME. Notes about Achatina (Lissachatina) fulica (Bowdich, 1822). Dangerous African Snail (Pulmonata Achatinidae) introduced in Venezuela. Acta Biologica Venezuelica 17: 37-40, 1997.

11. Maurer RL, Graeff-Teixeira C, Thomé JW, Chiaradia LA, Sugaya $\mathrm{H}$, Yoshimura K. Natural infection of Deroceras laeve (Mollusca: Gastropoda) with metastrongylid larvae in a transmission focus of Abdominal Angiostrongyliasis. Revista do Instituto de Medicina Tropical 44: 53-54, 2002.

12. Mendonça CLGF, Carvalho OS, Mota EM, Pelajo-Machado M, Caputo LFG, Lenzi HL. Penetration sites of and migratory routes of Angiostrongylus costaricensis in the experimental intermediate host (Sarasinula marginata). Memórias do Instituto Oswaldo Cruz 94: 549-556, 1999.

13. Morera $P$, Céspedes R. Angiostrongilosis abdominal. Una nueva parasitosis humana. Acta Médica Costarricense 14: 159-173, 1971.

14. Paiva CL. Achatina fulica (Moluscos) nova praga agrícola e ameaça à saúde pública no Brasil. Disponível em: www.intermega.com.br, 2001.

15. Teles HMS, Vaz JF, Fontes LR, Domingos MF. Registro de Achatina fulica Bowdich, 1822 (Mollusca, Gastropoda) no Brasil: caramujo hospedeiro intermediário da angiostrongilíase. Revista de Saude Publica 31: 310-312, 1997.

16. Thiengo SC, Amato SB, Aventino A, Araújo JLB. Estudo sobre os hospedeiros intermediários do Angiostrongylus costaricensis Morera and Céspedes, 1971. Revista Brasileira de Parasitologia Veterinária 2: 64, 1993.

17. Santos SB, Monteiro DP, Thiengo SC. Achatina fulica (Mollusca, Achatinidae) na llha Grande, Angra dos Reis, Rio de Janeiro: Implicações para a saúde ambiental. Biociências 10: 159-162, 2002.

18. Vasconcellos MC, Pile E. Ocorrência de Achatina fulica no Vale do Paraíba, Estado do Rio de Janeiro, Brasil. Revista Saúde Pública 35: 582-584, 2001.

19. Wallace GD, Rosen $L$. Techniques for recovering and identifying larvae of Angiostrongylus cantonensis from mollusks. Malacology 7: 427-438, 1969. 